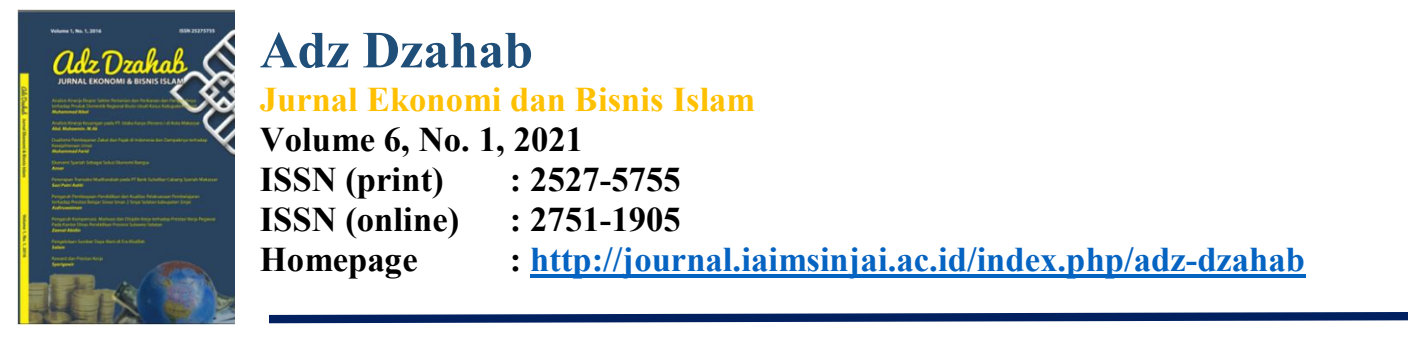

\title{
EFEKTIFITAS PENGELOLAAN DANA DESA DALAM UPAYA MENINGKATKAN PEMBANGUNAN YANG ISLAMI DI DESA PATILERENG
}

\author{
Agus Ashari ${ }^{1}$, Jumardi $^{2}$, Salam $^{3}$, Wahidayanti $^{4}$, Srianti Permata $^{5}$ \\ ${ }^{1}$ Universitas Muhammadiyah Makassar \\ 2,3,4,5 Institut Agama Islam Muhammadiyah Sinjai \\ e-mail:agus.ashari@gmail.com Tlp:
}

\begin{abstract}
Abstrak
Pengelolaan dana desa pada ruang lingkup pembangunan ekonomi umat menjadi bagian dari upaya untuk mensejahterakan desa sesuai dengan tujuan peruntukan dana desa. Penelitian ini bertujuan untuk mengetahui efektivitas pengelolaan dana desa dalam upaya meningkatkan pembangunan di Desa Patilereng Kecamatan Bontosikuyu Kabupaten Kepulauan Selayar dan untuk mengetahui pembangunan di Desa Patillereng sudah termasuk pembangunan yang islami ditinjau dari perspektif islam. Jenis penelitian yang digunakan adalah penelitian kualitatif deskriptif. Teknik pengambilan data dilakukan dengan cara wawancara, dokumentasi, wawancara. Hasil penelitian menunjukkan bahwa efektivitas pengelolaan dana desa dalam upaya meningkatkan pembangunan di desa Patilereng Kecamatan Bontosikuyu Kabupaten Kepulauan Selayar dinilai efektif karena diperoleh dari beberapa point yaitu: tepat kebijakan, dengan adanya pembangunan di desa masyarakat mudah dalam akses kesehariannya, tepat pelaksanaan, pemerintah desa melakukan kerjasama dengan masyarakat dan swasta dalam meningkatkan pembangunan. Tepat target, pembangunan di desa Patilereng telah dilaksanakan sesuai dengan target penyelesaiannya. Sedangkan menurut perspektif islam dapat dinilai dari bebebapa point yaitu: prinsip tauhid, nubuwah, kepemilikan, keseimbangan, keadilan, maslahah, persaudaraan dan tolong menolong.
\end{abstract}

Kata kunci: Pengelolaan Dana Desa, Pembangunan Islami.

\section{Pendahuluan}

Pemerintah Indonesia terus mengupayakan peningkatan pelaksanaan pembangunan nasional agar laju pembangunan daerah serta laju pembangunan desa semakin seimbang. Namun pembangunan nasional di Indonesia pada pelaksanaannya masih di hadapkan dengan masalah pokok pembangunan seperti ketimpangan pembangunan antara desa dan kota. Ketimpangan pembangunan terjadi karena banyak faktor yang memengaruhinya sehingga pembangunan di Indonesia tidak merata sehingga berdampak pada tingginya kemiskinan. Menanggapi permasalahan terkait dengan kemiskinan, strategi pemerintah untuk mengatasi ketimpangan tersebut yaitu dengan melaksanakan pembangunan nasional yang menaruh perhatian besar terhadap pembangunan desa. 


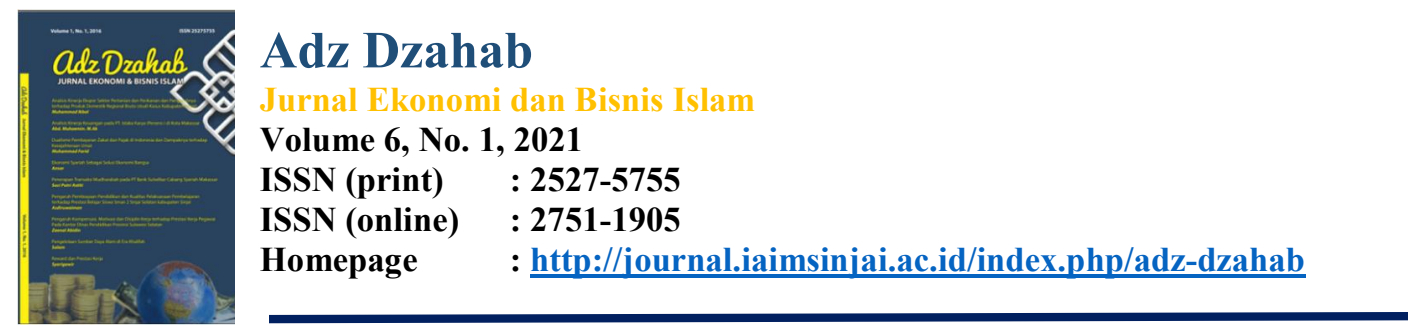

Dalam pelaksanaan pemerintahan desa, dituntut adanya suatu aspek tata pemerintahan yang baik (good governance), di mana salah satu karakteristik atau unsur utama dari good governance adalah akuntabilitas. Akuntabilitas dapat diartiartikan sebagai bentuk tanggungjawab pelaksanaan misi organisasi dalam mencapai tujuan yang telah ditetapkan melalui media pertanggungjawaban yang dilaksanakan secara periodik. Jadi, akuntabilitas pemerintahan sangat diperlukan sebagai penunjang penerapan otonomi desa agar dapat berjalan dengan baik (Putriyanti, 2012).

Desa adalah entitas terdepan dalam segala proses pembangunan bangsa dan negara. Hal ini menyebabkan desa memiliki arti sangat strategis sebagai basis penyelenggaraan pelayanan publik dan memfasilitasi pemenuhan hak-hak publik rakyat lokal. Sejak masa penjajahan Hindia Belanda sekalipun, pemerintah kolonial telah menyadari peran strategis desa dalam konstelasi ketatanegaraan pada masa itu. Di samping itu, desa menjadi arena politik paling dekat bagi relasi antara masyarakat dengan pemegang kekuasaan (perangkat Desa).

Alokasi Dana Desa (ADD) adalah dana yang diberikan kepada desa yang berasal dari dana perimbangan keuangan pemerintah pusat dan daerah yang diterima oleh Kabupaten/Kota. Pemberian ADD merupakan wujud dari pemenuhan hak desa untuk menyelenggarakan otonominya agar tumbuh dan berkembang mengikuti pertumbuhan dari desa itu sendiri berdasarkan keanekaragaman, partisipasi, otonomi asli, demokratisasi, pemberdayaan masyarakat dan meningkatkan peran pemerintah desa dalam memberikan pelayanan dan meningkatkan kesejahteraan masyarakat serta memacu percepatan pembangunan dan pertumbuhan wilayah-wilayah strategis. ADD sangat penting untuk pembiayaan pengembangan wilayah tertinggal dalam suatu sistem wilayah pengembangan. Pelaksanaan ADD ini ditujukan untuk program-program fisik dan non

fisik yang berhubungan dengan indikator perkembangan desa, meliputi tingkat pendidikan, tingkat pendapatan masyarakat, dan tingkat kesehatan.

Pembangunan desa akan semakin menantang di masa depan dengan kondisi perekonomian daerah yang semakin terbuka dan kehidupan berpolitik yang lebih demokratis. Akan tetapi desa sampai saat ini masih belum beranjak dari profil lama yakni terbelakangan dan miskin. Meskipun banyak pihak mengakui bahwa desa mempunyai peranan yang besar bagi kota, namun tetap saja desa dipandang rendah dalam hal ekonomi ataupun hal yang lainnya. Padahal kita ketahui bahwa sebagian besar penduduk Indonesia berdiam di daerah pedesaan dan berpropesi sebagai petani dan nelayan. Oleh karena itu, sudah sewajarnya bila pembangunan oedesaan harus menjadi prioritas utama dalam segenap rencana strategi dan kebijakan pembangunan di Indonesia (Hernowo, 2004).

Pembangunan desa mempunyai peranan yang sangat penting dan strategis dalam rangka Pembangunan Nasional dan Pembangunan Daerah, karena di dalamnya terkandung unsur pemerataan pembangunan dan hasil-hasilnya serta menyentuh secara langsung kepentingan sebagian besar masyarakat yang bermukim di pedesaan dalam rangka upaya meningkatkan kesejahteraan mereka. Dan, dalam pembangunan desa, pemerintah desa berkedudukan sebagai subsistem dari sistem penyelenggaraan pemerintah di Indonesia, sehingga desa memiliki kewenangan, tugas dan kewajiban untuk mengatur dan mengurus kepentingan masyarakatnya sendiri atau dikenal dengan otonomi daerah.

Dalam menyelenggarakan kewenangan, tugas dan kewajiban desa dalam penyelenggaraan pemerintahan maupun pembangunan maka dibutuhkan sumber 


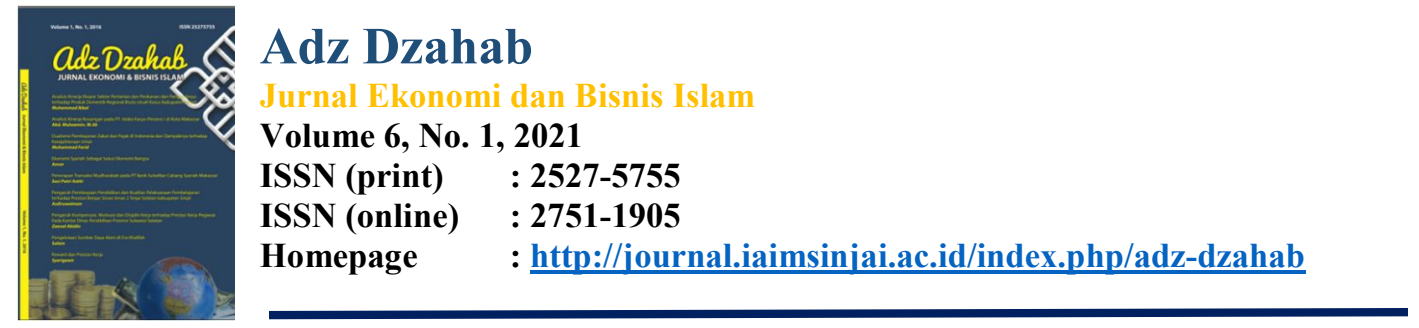

pendapatan desa. Oleh karena itu, pemerintah mengeluarkan kebijakan PP No 82016 tentang Dana Desa, berupa dukungan keuangan yaitu dana desa yang yang bersumber dari Anggaran Pendapatan Belanja Negara (APBN) yang diperuntukkan bagi desa yang ditransfer melalui Anggaran Pendapatan Belanja Daerah (APBD) Kabupaten/Kota dan digunakan untuk membiayai penyelenggaraan pemerintah, pelaksanaan pembangunan, pembinaan kemasyarakatan, dan pemberdayaan masyarakat.

Pembangunan desa seharusnya dilakukan dengan kerja sama antara pihak pemerintah desa, swasta maupun masyarakat. Jika hanya dilakukan oleh satu pihak saja, maka pembangunan yang dilaksanakan tidak akan terwujud dengan baik dan tidak akan mencapai sasaran yang telah direncanakan. Untuk mencapai sasaran tersebut pembangunan di desa khususnya, maka pemerintah diharapkan dapat terus berusaha melaksanakan program pembangunan yang diperuntukkan khusus bagi desa.

Pengelolaan dana desa pada ruang lingkup pembangunan ekonomi umat menjadi bagian dari upaya untuk mensejahterakan desa sesuai dengan tujuan peruntukan dana desa. Oleh karena itu, dalam alokasi dana desa perlu memperhatikan aspek pembangunan ekonomi umat, yakni melalui Badan Usaha Milik Desa (BUMDes). Pengembangan ekonomi umat melalui peningkatan produk dan fasilitas ekonomi juga didukung melalui Keputusan Menteri Desa Pembangunan Daerah Tertinggal dan Transmigrasi Nomor 48 Tahun 2018 tentang Pedoman Umum Program Inovasi desa yang disingkat PID.

PID dirancang untuk mendorong dan memfasilitasi penguatan kapasitas Desa yang diorientasikan untuk memenuhi pencapaian target RPJM, dan program prioritas Kementerian Desa PDTT, melalui peningkatan produktivitas perdesaan dengan bertumpu pada: 1) pengembangan ekonomi lokal dan kewirausahaan, baik pada ranah pengembangan usaha masyarakat, maupun usaha yang diprakarsai Desa melalui Badan Usaha Milik Desa (BUMDesa) dan Badan Usaha Milik Desa Bersama (BUMDesa Bersama), serta Produk Unggulan Desa (Prudes) dan Produk Unggulan Kawasan Perdesaan (Prukades) guna menggerakkan dan mengembangkan perekonomian Desa; 2) peningkatan kualitas sumber daya manusia (SDM), kaitan antara produktivitas perdesaan

dengan kualitas SDM ini diharapkan terjadi dalam jangka pendek maupun dampak signifikan dalam jangka panjang melalui investasi di bidang pendidikan dan kesehatan dasar, produktivitas perdesaan, dengan demikian, tidak hanya ditilik dari aspek/strategi peningkatan pendapatan saja, tetapi juga pengurangan beban biaya dan hilangnya potensi di masa yang akan dating. Disamping itu, penekanan isu pelayanan sosial dasar (PSD) dalam konteks kualitas SDM ini juga untuk merangsang kepekaan desa terhadap permasalahan krusial terkait pendidikan dan kesehatand asar dalam penyelenggaraan pembangunan Desa; dan 3) pemenuhan dan peningkatan infrastruktur perdesaan, khususnya yang secara langsung berpengaruh terhadap perkembangan perekonomian Desa dan memiliki dampak menguat-rekatkan kohesi sosial masyarakat perdesaan (Peraturan Menteri Dalam Negeri No 20 Tahun 2018 Tentang Pengelolaan Keuangan Desa, 2018).

Pengelolaan dana desa dalam rangka mewujudkan pembangunan desa yang menjadi tugas aparat pemerintah desa untuk memajukan dan mensejahterakan masyarakat desa merupakan suatu amanah yang harus dipertanggungjawabkan sesuai dengan aturan yang berlaku. Pertanggungjawaban ini mencakup semua aspek yang telah dalam peraturan perundang-undangan Negara. Selain pertanggungjawaban berdasarkan ketentuan perundang-undangan, pengelola anggaran desa juga memperhatikan prinsip amanah sebagai wujud ekonomi ummat sebagaimana yang terdapat dalam QS. Annisa (58): 


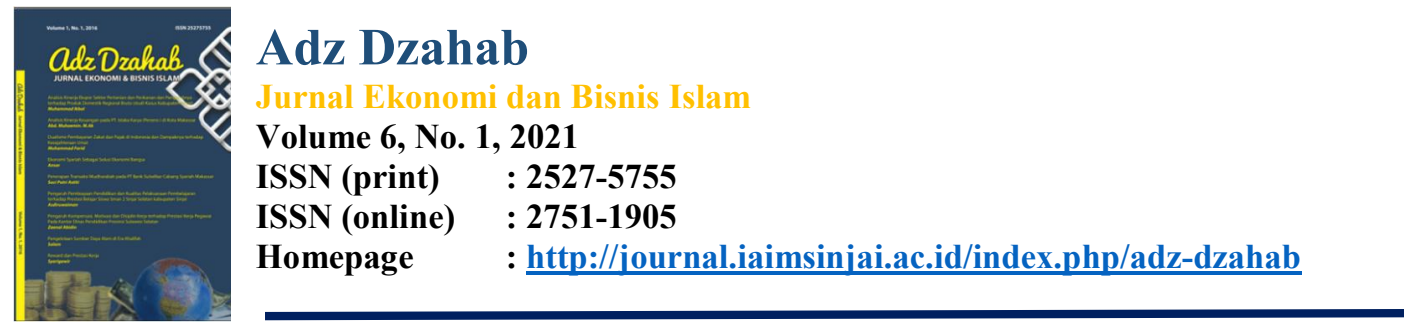

"Sesungguhnya Allah menyuruh kamu menyampaikan amanat kepada yang berhak menerimanya, dan (menyuruh kamu) apabila menetapkan hukum di antara manusia supaya kamu menetapkan dengan adil. Sesungguhnya Allah memberi pengajaran yang sebaik-baiknya kepadamu. Sesungguhnya Allah adalah Maha Mendengar lagi Maha Melihat".

Pengelolaan dana desa tidak serta merta mencapai target pembangunan desa atau kesejahteraan masyarakatnya. Hal ini dapat dilihat berbagai fenomena yang terjadi di beberapa desa justru masih jauh dari kata sejahtera, dan banyak pula dari beberapa perangkat desa terlibat dalam tindakan merugikan seperti penyelewengan dana atau korupsi. Dan menariknya adalah menurut pemerintah kabupaten Selayar bahwa rata-rata pengelolaan keuangan Desa sudah sesuai dengan arahan pemerintah daerah dan dianggap baik. Namun, fenomena di lapangan di beberapa desa menurut data pemerintah daerah menukjukkan bahwa kesejahteraan masyarakat miskin yang diukur dari pendapatan dan belanja masyarakat belum menunjukkan kondisi yang membaik. Kesejahteraan masih belum dirasakan oleh masyarakat miskin. Hal tersebut mengindikasikan bahwa pengelolaan anggran yang baik tidak serta merta menjamin kesejahteraan masyarakatnya. Padahal, tujuan dari alokasi anggaran desa adalah untuk memenuhi kebutuhan ekonomi masyarakatnya.

Berbeda dengan Desa Pattilireng, di mana tersebut merupakan salah satu desa yang termasuk baik dalam pengelolaan anggaran desa, dan mampu memberik efek positif terhadap kesejahteraan bagi masyarakat. Oleh karena itu, peneliti tertarik untuk meneliti pola pengelolaan anggaran desa tersebut untuk mengemukakan bagaimana efektivitas dana desa dalam bidang pembangunan, sekaligus sebagain kajian untuk mengintegrasikan bagaiaman pengelolaan dana desa sesuai dengan prinsip ekonomi ummat sebagai dasar untuk mewujudkan kesejahteraan masyarakat khususnya di Desa Patileraeng? Peneliti mengguna-kan konsep pembangunan islam sebagai salah satu kajian karena Desa Pattilireng dalam praktiknya lebih banyak menggunakan prinsip-prinsip ekonomi ummat sebagai dasar kebijakan pengelolaan anggaran desa.

\section{Metode Penelitian}

Jenis penelitian yang digunakan adalah penelitian kualitatif deskriptif. Metode kualitatif di lakukan dengan cara penelitian datang ke lokasi menggunakan alat kualitatif, kerangka berpikir kualitatif, dan data yang di kumpulkan juga data-data kualitatif, kecuali untuk beberapa gejala tertentu yang bersifat perhitungan di kumpulkan juga data kualitatif.

Fokus penelitian ini mengemukakan tentang penerapan masalah yang menjadi pusat perhatian penelitian, di mana penelitian ini diarahkan pada pengelolaan Dana Desa dalam meningkatkan pembangunan yang Islami. Penelitian ini dilakukan di Desa Pattilereng, Kecamatan Bontosikuyu, Kabupaten Kepulauan Selayar.

Jenis dan Sumber data yang digunakan dalam penelitian ini adalah Data primer dan sekunder. Data primer diperoleh dari hasil wawancara langsung dari tokoh masyarakat dan staf desa. Data primer dikumpulkan melalui wawancara mendalam (indept interview) dan kuisioner. Sementara data sekunder diperoleh dari informasi-informasi atau hasil dari penelitian, buku referensi, media massa, internet dan lain sebagainya yang menunjang dengan masalah yang di teliti. Selanjutnya dilakukan proses analisa terhadap data yang telah dikumpulkan sehingga data yang telah dikumpulkan sehingga data yang ada akan saling melengkapi.

Untuk memperoleh data penelitian, teknik pengumpulan data yang digunakan peneliti adalah dengan melakukan penelitian kepustakaan dan penelitian lapangan. 


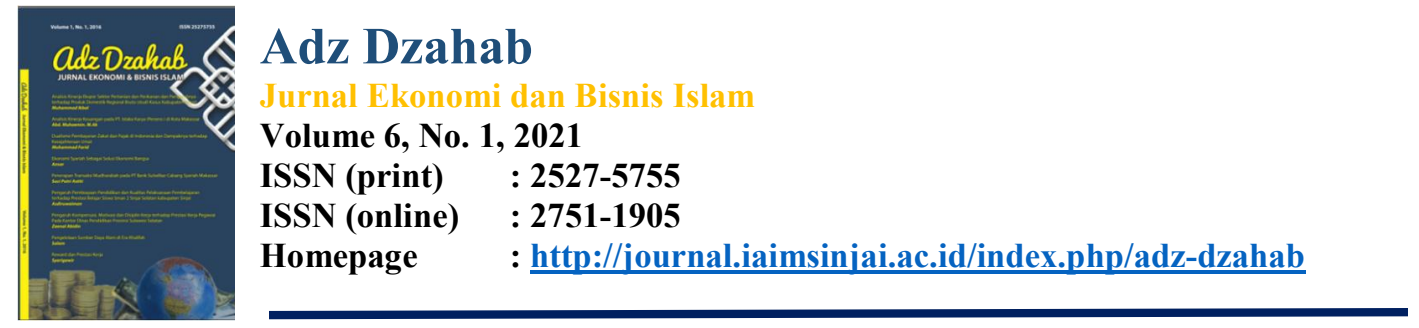

Penelitian kepustakaan, mencari data sekunder yaitu data yang bersumber dari catatan yang ada pada perusahaan dan dari sumber lainnya yaitu dengan mengadakan studi kepustakaan dengan mempelajari buku-buku yang ada hubungannya dengan objek penelitian. Dan, penelitian lapangan untuk memperoleh data secara akurat dengan melakukan studi lapangan berupa observasi lapangan dan wawancara.

Selanjutnya analisis data untuk menganalisis data yang terkumpul, peneliti menggunakan metode penelitian deskriptif yaitu penelitian yang bermaksud untuk membuat deskriptif mengenai situs-situs atau kejadian-kejadian. Penelitian deskriptif bertujuan menggambarkan secara sistematik dan akurat fakta dan karakteristik mengenai populasi dan bidang tertentu. Dalam rangka menjawab rumusan masalah yang ditetapkan peneliti, maka analisis data yang menjadi acuan dalam penelitian ini mengacu pada beberapa tahapan yang yaitu reduksi data, penyajian data dan penarikan kesimpulan.

\section{Hasil Penelitian Dan Pembahasan}

\subsection{Hasil Penelitian}

\subsubsection{Efektivitas Dana Desa di Desa Patilereng, Kecamatan Bontosikuyu, Kabupaten Kepulauan Selayar}

Dana desa merupakan dana yang bersumber dari APBN yang diperuntukkan untuk desa setiap tahun. Dana tersebut digunakan untuk pembangunan desa demi tercapainya pembangunan nasional. Setiap tahun, desa memperoleh Dana Desa hingga 1 (satu miliyar). Dalam penggunaannya, 30\% dari Dana Desa digunakan untuk operasional. Sedangkan $70 \%$ digunakan untuk pembangunan. Dana Desa dikatakan efektif apabila dana tersebut digunakan sesuai dengan tujuan dari adanya kebijakan Dana Desa sendiri. Dana Desa ada untuk mewujudkan pembangunan di Desa.

Berdasarkan penelitian mengenai efektivitas Dana Desa di Desa Patilereng Kecamatan Bontosikuyu Kabupaten Kepulauan Selayar, ditemukan beberapa informasi yang mampu menjelaskan bagaimana efektivitas Dana Desa di Desa Patilereng Kecamatan Bontosikuyu Kabupaten Kepulauan Selayar. Dalam memperoleh informasi, peneliti menggunakan beberapa aspek untuk mengukur efektivitas Dana Desa. Adapun aspek yang akan dikaji oleh peneliti meliputi:

\section{a. Perencanaan}

Tahap perencanaan Pengelolaan Dana Desa di Desa Patilereng Kecamatan Bontosikuyu Kabupaten Kepulauan Selayar, telah sesuai dengan aturan yaitu pembentukan tim pelaksana dalam kegiatan Musrembang. Tim pelaksana Dana Desa yang di maksud terdiri dari Kepala Desa selaku penanggungjawab operasi kegiatan (POJK), Sekretaris desa selaku penanggungjawab administrasi (PJAK), bendahara desa selaku kepala urusan keuangan (KUK) dan dibantu oleh lembanga kemasyarakatan di desa.

Perencanaan dilakukakan melalui Musrembang desa dengan melibatkan seluruh elemen masyarakat yang terdiri dari lembaga masyarakat, toko masyarakat dan seluruh masyarakat desa. Musrembang desa adalah singkatan musyawarah perencanaan pembangunan yang bertujuan mendorong seluruh masyarakat agar turut serta berpartisipasi dalam kegiatan perencanaan pembangunan di desa.

Hasil pengamatan dan informasi yang diperoleh bahwa kegiatan musrembang dalam tahapan perencanaan di Desa Patilereng Kecamatan Bontosikuyu Kabupaten Kepulauan Selayar masih sebatas menghadiri dan masih kurang yang mengerti apa tujuan Musrembang tersebut. 


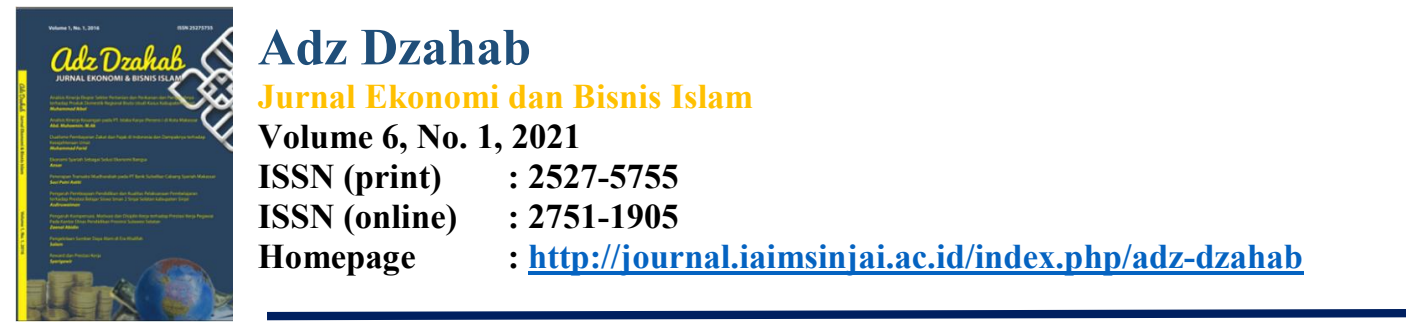

Menurut Bapak Saharuddin Arif selaku Kepala Desa Patilereng mengenai perencanaan Pengelolaan Dana Desa dan partisipasi masyarakat desa dalam kegiatan Musrembang mengatakan bahwa:

"Dalam proses musrembang yang dilakukan, partisipasi masyarakat dalam kegiatan ini masih kurang dan so'di sikali masyarakat tu sare saran untuk kegiatan musrembang inni. Mungkin di sebabkan karena masyarakat mempunyai kesibukan tersendiri dan juga kepedulian masyarakat bisa di bilang masih kurang." (Wawancara 2019)

Adapun informasi yang diperoleh dari masyarakat bahwa dalam kegiatan Musrembang pemerintah bisa dikatakan baik dalam memberikan informasi kepada masyarakat. Pernyataan dari bapak Misba yang mengatakan bahwa:

"ampa la rapat musrembang, pamarentah desa biasa la sarekang undangan untuk menghadiri rapat injo. Dan masayarakat biasana diberikan kesempatan untuk assare sarang terkait pembangunan di desa Patilereng." Artinya setiap akan di adakan rapat pemerintah desa memberikan undangan kepada Lembaga masyarakat untuk menghadiri rapat tersebut."(Wawancara 2019)

Jadi, secara keseluruhan proses perencanaan kegiatan pengelolaan dana desa dalam meningkatkan pembangunan di Desa Patilereng Kecamatan Bontosikuyu Kabupaten Kepulauan Selayar di tentukan dengan musyawarah perencanaan pembangunan oleh pemerintah desa sekalu tim pelaksana pengelolaan dana desa dalam meningkatkan pembangunan. Adapun hasil wawancara dengan Bapak Yusriadi selaku ketua BPD mengatakan bahwa:

"kegiatan Musrembang mampu menghasilkan berbagai rencana kegiatan dalam penggunaan Dana Desa bisa dikatakan berjalan dengan baik karena masayarakat ikut serta dalam perencanaan yang dirapatkan dalam kegiatan Musrembang, contohnya jalan tani ataupun yang lainnya."

Dari hasil wawancara dengan beberapa informan pada tahap perencanaan yaitu bapak Saharuddin Arif, Bapak Misba, dan Bapak Yusriadi. Penelitian menemukan hasil bahwa masyarakat ikut berpartisipasi dalam kegiatan musrembang dan pemerintah juga

memberikan kesempatan bagi masyarakat untuk memberikan saran untuk tahapan perencanaan pembangunan dalam pengelolaan dana desa dalam meningkatkan pembangunan yang islami di Desa Patilereng Kecamatan Bontosikuyu Kabupaten Kepulauan Selayar.

b. Tahap Pelaksanaan

Indikator kedua dalam melihat suatu efektivitas yaitu melihat apakah dalam pelaksanaannya sudah tepat atau tidak dalam bidang pembangunan. Dalam ketepatan peksanaan dana desa dibagi atas tupoksi masing-masing di bidang pembangunan. Meskipun tujuan dana desa adalah untuk mewujudkan pembangunan, namun pembangunan di sini bukan diartikan sebgai infrastruktur saja. Namun pembangunan terdiri dari pembangunan infrastruktur dan pemberdayaan masyarakat. Pembangunan infrastruktur adalah pembangunan dalam bentuk fisik yang membantu masyarakat patilereng dalam kegiatan sehari-harinya. Sedangkan pemberdayaan masyarakat adalah bagaimana masyarakat patilereng dibina agar terciptanya individu ataupun masyarakat mandiri. 


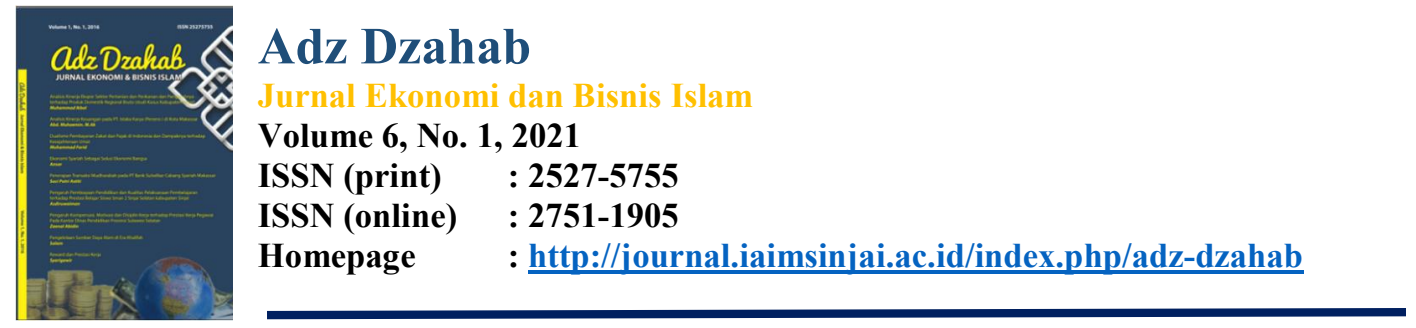

Pembangunan infrastruktur yang ada di Desa Patilereng adalah pembangunan jalan tani untuk masyarakat, pembangunan WC bagi masyarakat yang tidak punya jambang, pembangunan jalan setapak, pembangunan pasar pakampong, serta pembangunan yang dibutuhkan oleh masyarakat. Sedangkan pemberdayaan masyarakat berupa penyuluhan, sosialisasi, pelatihan menjahit sehingga dapat diaplikasikan dalam kehidupan sehari-hari oleh masyarakat Patilereng. Sehingga dalam ketepatan pelaksanaannya dari dana desa dapat diukur dari bagaimana kerjasama antara pemerintah, swasta dan masyarakat di Desa Patilereng Kecamatan Bontosikuyu Kabupaten Kepulauan Selayar.

Pelaksanaan pembangunan dinilai tepat apabila terjalin kerjasama dengan pihakpihak tertentu. Baik dari pemerintah, swasta, maupun masyarakat. Maksudnya adalah pertama, pelaksanaan pemberdayaan masyarakat yang dilakukan oleh pemrintah. Kedua, pembangunan infrastruktur yang beskala menengah atau kecil yang diselenggarakan oleh masyarakat. Dari hasil penelitian di Desa Patilereng, pelaksanaannya menurut informasi yang dituturkan oleh Ketua TPK (Tim Pelaksana Khusus), Bapak Irwan bahwa:

"biasana injo Dana Desa terlambat I cair, tapi geleji gassing pakonjo. Jari na rie rencana pembangunan tapi tidekpa dana larigunakan, biasana pamarentah bekerjasama ie dengan pihak swasta. Misalnya rie bahan nu gele ganna kullekingera ri pihak swasta rolo manna cairpi dana desa injo ampai ribajara." (Dana Desa biasanya terlambat cair, tapi tidak sering-sering. Jadi kalau ada rencana pembangunan yang akan dilaksanakan oleh pemerintah desa tapi dana tidak mencukupi atau tidak ada pihak pemerintah bisa bekerjasama dengan pihak swasta terkait bahan yang diperlukan dalam pembangunan tersebut). "Dalam pelaksanaan pembangunan seperti Jalan Tani, Jalan seapak ataupun pembangunan yang lain biasanya melibatkan masyarakat patilereng," lanjutnya.

Dari pernyataan Ketua Tim Pelaksana Khusus (TPK) menyebutkan bahwa pemerintah desa melakukan kerja sama dengan pihak swasta. Kerja sama yang di maksud yaitu pembelian bahan material yang diperlukan dalam pembangunan yang akan dilaksanakan oleh pemerintah/Desa Patilereng. Alur kerjasama tersebut adalah di mana pihak pemerintah membeli bahan bangunan yang akan dipergunakan dan pembayaran atau transaksinya dibayarkan di akhir. Pembayaran akhir dilakukan oleh pemerintah karena terlambatnya Pencairan Dana Desa dari Pemerintah Daerah.

Selain kerjasama yang dilakukan oleh pemerintah Desa Patilereng dengan pihak swasta, pemerintah desa juga melakukan kerja sama dengan melibatkan masyarakat. Pada

pembangunan di Desa Patilereng tidak serta merta melibatkan pemerintah Desa saja. Sebelum melaksanakan pembangunan infrastruktur, pemerintah desa merangkul atau mengumpulkan masyarakat untuk ikut serta dalam perencanaan yang dilakukakan oleh pemerintah desa dengan masyarakat Desa Patilereng. Hal ini dikatakan oleh Bapak Mansur Selaku Sekretaris Desa Patilereng:

"Pembangunan di Desa Patilereng telah direncanakan dan sudah di sepakati bersama warga atau masyarakat di sini. Setiap bulan kami mengadakan musyawarah yang di hadiri oleh kepala desa, Perangkat Desa, Ketua RT, Ibu PKK serta perwakilan dari Warga/masyarakat di sini." (Wawancara, 2019) 




Pernyataan di atas didukung oleh pernyataan Bapak Irwan Rasyid bahwa:

"nabai injo nak. Biasana awal bulan atau pertengahan bulan rie'mo undangan mange rapat rikantor desa. Injo ribahas apa kendala masyarakat dan apa laripa'rie supaya masyarakat terbantui. (Betul itu nak, biasanya awal atau pertengahan bulan sudah ada panggilan rapat di kantor desa dengan pembahasan mengenai apa kendala masyarakat dalam hal pembangunan." (Wawancara, 2019)

Dari Pernyataan di atas dapat disimpulkan bahwa setiap bulan Pemerintah Desa Patilereng melaksanakan Rapat atau Musyawarah untuk membahas perencanaan pembangunan ke depannya. Rapat tersebut dihadiri oleh Kepala Desa, Perangkat Desa, Ketua RT, dan masyarakat/warga di desa Patilereng. Sehingga kerja sama dalam bentuk rapat atau musyawarah ini sangat diperlukan untuk kebutuhan pembangunan kedepannya. Selain itu, pemerintah Desa Patilereng juga menunjuk langsung masyarakat yang ahli dalam bidangnya sebagai pelaksana pembangunan tersebut. Artinya pemerintah desa memberikan kepercayaan penuh kepada warganya untuk melakukan pembangunan infrastruktur yang akan diilakukan.

Kedua adalah Pembangunan di bidang pemberdayaan masyarakat. Pembangunan pemberdayaan masyarakat di Desa Patilereng berupa kegiatan Keluarga berencana (KB) dan pelatihan jahit. Penyuluhan ini dilaksanakan pemerintah desa yang bekerja sama dengan narasumber yang bersangkutan. Sedangkan objek yang akan menerima penyuluhan ini adalah masyarakat Patilereng. Dengan adanya penyuluhan ini, pemerintah Desa Patilereng berharap kepada masyarakat agar dapat mengaplikasikan apa yang telah didapatkan dalam kegiatan pemberdayaan tersebut. Hal tersebut disampaikan oleh PJS Desa Patilereng:

"Pembinaan itu ada dilakukan di Posyandu maupun di kantor Desa Patilereng. Kemarin sudah ada kegitan yang dilaksanakan oleh Pemerintah Desa yakni pelatihan Menjahit untuk ibu-ibu di desa Patilereng yang mempunyai hobi atau kemampuan dalam bidang jahit dan penyuluhan tentang keluarga berencana (KB)."

Seperti yang sudah ditulis di atas, yang mengatakan bahwa ketepatan pelaksanaan dana desa dinilai tepat apabila pelaksanaan pembangunan di bidang pemberdayaan masyarakat diselenggarakan oleh pemerintah desa Patilereng. Kedua, pembangunan di bidang infrastruktur berskala menengah dan kecil diselenggarakan oleh masyarakat. Melihat tolak ukur tersebut, melalui penelitian ini dapat disimpulkan bahwa pelaksanaan pembangunan di Desa Patilereng dapat dinilai tepat.

c. Tahap Pertanggungjawaban

Tahap penyelesaian penyusunan pertanggungjawaban pengelolaan dana desa dalam meningkatkan pembangunan di Desa Patilereng Kecamatan Bontosikuyu Kabupaten

Kepulauan Selayar, dalam tahap ini bisa dikatakan efektif, karena penyusunan laporan pertanggungjawaban (LPJ) disusun oleh pemerintah desa Patilereng secara transparan dan bisa diketahui oleh seluruh masyarakat desa Patilereng. Berdasarkan wawancara oleh ibu riskayanti Staff desa Patilereng yang menyatakan bahwa:

"kualitas SDM pemerintah Desa Patilereng tergolong baik, karena ada yang sudah sarjana yang direkrut untuk mengabdi di pemerintah desa dan pemerintah desa sudah berpengalaman dalam bidang pengelolaan dana desa dan biasanya itu 


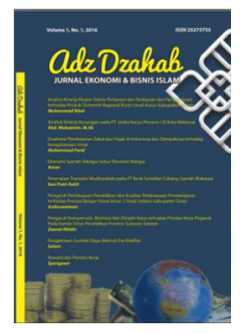

Adz Dzahab

Jurmal Ekonomi dan Bisnis Islam

Volume 6, No. 1, 2021

ISSN (print) : 2527-5755

ISSN (online) : 2751-1905

Homepage : $\quad$ http://journal.iaimsinjai.ac.id/index.php/adz-dzahab

pelaporan LPJ dilakukan di Bapendes (Badan Pemberdayaan Masyarakat dan Pemerintah Desa)"

Pernyataan di atas didukung oleh hasil wawancara dengan Bapak Saharuddin Arif selaku Kepala Desa Patilereng, yang menyatakan bahwa:

"yang membuat SPJ (Surat pertanggungjawaban) adalah TPK (Tim Pelaksana Kegiatan) dibantu oleh operator Siskudes dan Kaur Keuangan (Bendahara Desa) diverifikasi oleh Sekdes selaku Koordinator PPKD dan disetujui oleh kepala desa selaku PKPKD (Pemendagri 20 Tahun 2018).” (Wawacara: 2019)

Laporan pertanggungjawaban yang dibuat dapat diterima dengan baik oleh pemerintah kabupaten (Bapendes). Adapun Hasil wawancara dengan pihak BPD yang mengatakan bahwa:

"Pemerintah desa patilereng sangat baik dalam pentusunan laporan pertanggungjawaban atas penggunaan Dana Desa ini. Dalam LPJ yang dibuat tidak pernah ada masalah yang didapat oleh TIM BPD (Pemeriksa).” (Wawancara 2019)

Salah satu prinsip pengelolaan Dana Desa ini bahwa seluruh kegiatan harus dievaluasi bersama masyarakat. Hal ini diterapkan oleh pemerintah Desa Patilereng dalam mengevaluasi laporan pertanggungjawaban guna memberikan informasi terkait pembangunan yang telah dilaksanakan oleh pemerintah Desa Patilereng.

\subsubsection{Pengelolaan Dana Desa dalam Upaya Meningkatkan Pembangunan}

Berdasarkan Konsep Pembangunan Islami Di Desa Patilereng Kecamatan

Bontosikuyu Kabupaten Kepulauan Selayar.

Upaya-upaya pemerintah desa dalam meningkatkan pembangunan sangat berkaitan dengan peran pemerintah itu sendiri dalam proses pembangunan. Aktifitas pembangunan ini diharapkan dapat membantu masyarakat desa dalam bidang perekonomian dan kepentingan rakyat desa secara umum. Selain itu, segala aktivitas pembangunan yang ada di desa bisa membawa perubahan bagi masyarakat dari segi kehidupannya.

Beberapa upaya yang dilakukan oleh pemerintah desa dalam meningkatkan pembangunan adalah sebagai berikut:

a. Pembangunan sektor jalan

Dalam pelaksanaan di bidang pembangunan, pemerintah desa patilereng telah melaksanakan beberapa kegiatan yaitu pembangunan jalan umum dan jalan tani. Dalam wawancara dengan Bapak Hasbi, dikatakan bahwa:

"kambe inni masyarakat desa Patilereng attarima kasihkang mange ri pamarentah desa saba' labuakangkan Lalang mange ri koko surngan pole la la paka baji Lalang nu da.a injo mange ri dusun-dusun"

Dapat dikatakan bahwa pembangunan yang dilaksanakan oleh pemerintah desa Patilereng itu pasti dari permintaan masyarakat. Dan pembangunan jalan yang dilakukan bisa bermanfaat bagi kehidupan masyarakat desa dan memberdayakan masyarakat di desa Patilereng.

b. Pembangunan Pos Pelayanan Terpadu (POSYANDU), masjid, sanngar seni.

Posyandu merupakan salah satu upaya di bidang kesehatan yang bersumber dari masyarakat, dikelola dan diselenggarakan dari, oleh dan untuk bersama yang bertujuan 


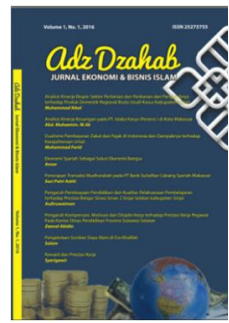

Adz Dzahab

Jurnal Ekonomi dan Bisnis Islam

Volume 6, No. 1, 2021

ISSN (print) : 2527-5755

ISSN (online) : 2751-1905

Homepage : $\quad$ http://journal.iaimsinjai.ac.id/index.php/adz-dzahab

untuk memberdayakan masyarakat di desa Patilereng. Mesjid merupakan salah satu upaya untuk meningkatkan pembangunan yang bersifat islami karena dijadikan tempat untuk beribadah di desa Patilereng.

c. Pembangunan Badan usaha milik desa (BUMDES)

Pemerintah desa melakukan pemberdayaan di bidang ekonomi yaitu dengan mengadakan BUMDES yang bertujuan meningkatkan perekonomian masyarakat. Program ini salah satuya adalah pelatihan menjahit dan tempat wisata Punagaan. Dalam kegiatan ini pemerintah mengalokasikan dana yang berasal dari dana desa.

Adanya pembangunan infrastruktur dalam islam memiliki dampak yang positif dalam segi ekonomi maupun sosial. Pembangunan di desa yang berdampak pada perekonomian masyarakat desa baik dari segi melakukan pekerjaan dan perdagangan yang dapat meningkatkan pendapatan masyarakat. Dalam ekonomi Islam, aktifitas ekonomi adalah bernilai ibadah, inilah yang kemudian memengaruhi segala perilaku dalam melakukan komsumsi, produksi, dan interaksi ekonomi lainnya.

Berdasarkan teori di atas, pembangunan yang dilakukan pemerintah desa Bersama masyarakat merupakan wujud keinginan masyarakat Desa Patilereng untuk lebih maju dan berkembang. Partisipasi masyarakat meningkat dengan adanya program Dana Desa dalam pembangunan dan pemberdayaan masyarakat yang bertujuan menciptakan kemaslahatan umat, kemandirian dan kepribadian yang bertanggungjawab. Pemerintah Desa Patilereng sangat terbantu dengan adanya Dana Desa dalam pembangunan sarana dan prasarana desa serta berjalannya program pemberdayaan masyakarat. Dalam wawancara dengan Bapak Udin dikatakan bahwa:

"Dengan program pembangunan menggunakan Dana Desa, pemerintah desa Patilereng mengajak seluruh masyarakat dalam peningkatan pembangunan, baik itu peningkatan sarana ibadah (Mesjid), Kesehatan (Posyandu), tempat wisata, pelatihan-pelatihan (seperti menjahit) ataupun memberikan penyuluhan terhadap petani di desa patilereng."

Berdasarkan ayat tersebut kandungan yang sangat jelas bahwa kewajiban seorang muslim dan manusia untuk selalu berusaha sekuat tenaga dan fikiran untuk memperoleh harta dan mencari harta tersebut dengan bersungguh-sungguh sesuai apa yang telah dianugrahkan oleh Allah SWT.

Manusia berkewajiban untuk berusaha dengan bersungguh-sungguh dalam menggunakan kemampuan yang dimilikinya dalam mencari, menggunakan dan memamfaatkan sumber daya yang ada di muka bumi, karena dalam ayat Al-Qashash telah disebutkan bahwa Allah tidak merubah suatu kaum melainkan hambanya yang merubah. Artinya, Allah telah membukakan jalan untuk manusia dalam menggunakan potensi dan kemampuan dalam pemberdayaan, tergantung kepada masyarakat dapat menggunakan dengan baik ataupun sebaliknya.

Untuk mengetahui efektivitas pengelolaan dana desa dalam upaya meningkatkan pembangunan di desa Patilereng. Hal ini dapat dilihat dari beberapa aspek yaitu: Perencanaan, pelaksanaan, dan pertanggungjawaban. Dari aspek ini dapat menjadi

pertimbangan untuk mengetahui efektivitas pengelolaan dana desa dalam upaya meningkatkan pembangunan di desa Patilereng sudah berjalan dengan bagus atau tidak. Untuk mengetahui efektivitas pengelolaan dana desa terhadap pembangunan yang islami ada beberapa prinsip antara lain: prinsip tauhid, prinsip nubuwah, kepemilikan, keseimbangan, keadilan, dan tolong-menolong. 


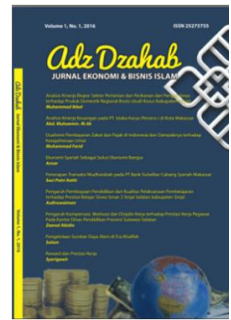

\subsection{Pembahasan}

\subsubsection{Efektivitas Dana Desa dalam Meningkatkan Pembangunan di Desa Patilereng Kecamatan Bontosikuyu Kabupaten Kepulauan Selayar}

Terkait pengelolaan dana desa dalam meningkatkan pembangunan di desa Patilereng Kecamatan Bontosikuyu Kabupaten Kepulauan Selayar, pemerintah desa Patilereng terlebih dahulu membuat tim pelaksana yang terdiri dari Kepala Desa selaku penanggungjawab operasional kegiatan (PJOK), Sekretaris Desa selaku penanggungjawab Administrasi Kegiatan (PJAK), Kepala Urusan Keuangan selaku Bendahara Desa dan dibantu oleh Lembaga Permasyarakatan di Desa. Selanjutnya pengelolaan Dana Desa terdiri dari perencanaan, pelaksanaan dan pertanggungjawaban.

Hasil penelitian menunjukkan bahwa tahapan perencanaan pengelolaan Dana Desa dalam meningkatkan pembangun di Desa Patilereng Kabupaten Selayar sudah efektif karena melihat proses Musyawarah Rencana Pembangunan (Musrembang) desa untuk membahas rencana kegiatan penggunaan anggaran serta bagaimana proses pengelolaan Dana Desa, di mana dalam tahapan perencanaan ini diukur dengan jumlah pihak yang berpartisipasi dalam proses Musrembang desa tersebut.

Selain itu, dalam tahapan perencanaan pengelolaan Dana Desa menunjukkan bahwa sudah banyak masyarakat yang berpartisipasi dalam mengikuti kegiatan musyawarah perencanaan pembangunan (Musrembang) di Desa Patilereng Kecamatan Bontosikuyu. Sehingga dalam proses perencanaan tersebut ada perwakilan ataupun masyarakat yang ikut andil dalam perencanaan tersebut, sehingga berdampak pada meningkatnya pembangunan di Desa Patilereng.

Hasil penelitian di atas dapat dibandingkan dengan penelitian terdahulu yang dilakukan oleh Hafid (2017), menyatakan bahwa pemanfaatan dana desa dalam pembangunan Desa Mangilu Kecamatan Bungoro Kabupaten Pangkep sudah efektif karena dilihat dari program pembangunan yang telah dilaksanakan sesuai dengan perencanaan yang ditetapkan oleh pemerintah di dalam rapat Musrembang dan keterlibatan masyarakat dalam pelaksanaan pembangunan tersebut. Hasil penelitian ini sejalan dengan penelitian Sofiyanto et al. (2017), Thomas (2013), Siti dan Hutami (2017), Sumianto (2018), dan Lili (2018). Sedangkan, penelitian yang dilakukan oleh Endang (2017) mengenai efektivitas pemamfaatan dana desa dalam menunjang pembangunan di kabupaten Asahan menyatakan bahwa pengelolaan dana desa tidak terlaksana dengan baik karena belum sepenuhnya sesuai dengan harapan masyarakatnya.

Pada tahap pelaksanaan pengelolaan dana desa di desa Patilereng, hasil peneltian menunjukkan bahwa dalam tahapan pelaksanaan pengelolaan dana desa di desa Patilereng baik karena adanya transparansi dari pemerintah ke masyarakat tentang Pengelolaan Dana Desa di Desa Patilereng. Dengan demikian, tahapan pelaksanaan pengelolaan dana desa dalam meningkatkan pembangunan di desa Patilereng berjalan baik karena melibatkan masyarakat selaku pekerja dan swasta sebagai pemberi bahan dalam pelaksanaan pembangunan tersebut.

Tahapan selanjutnya yaitu pertanggungjawaban pengelolaan dana desa di desa Patilereng. Hasil penelitian menunjukkan bahwa tahapan pertanggungjawaban sudah efektif/baik, di mana penyusunan Laporan pertanggunjawaban (LPJ) disusun oleh pemerintah desa yaitu TPK dibantu oleh Siskudes dan Kaur Keuangan (bendahara), selanjutnya diverifikasi oleh Sekdes selaku koordinator PPKD dan disetujui oleh Kepala Desa. Maka tahapan pertanggungjawaban yang dilakukan oleh pemerintah desa Patilereng dapat dikatakan efektif. 


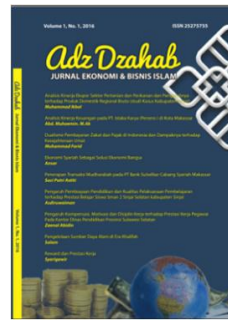

Volume 6, No. 1, 2021

ISSN (print) : 2527-5755

ISSN (online) : 2751-1905

Homepage : http://journal.iaimsinjai.ac.id/index.php/adz-dzahab

\section{Konsep Pembangunan Islami di Desa Patilereng Kecamatan Bontosikuyu Kabupaten Kepulauan Selayar}

Berdasarkan hasil penelitian di atas, pembangunan yang dilakukan pemerintah desa bersama masyarakat merupakan wujud keinginan masyarakat Desa Patilereng untuk lebih maju dan berkembang. Partisipasi masyarakat meningkat dengan adanya program Dana Desa dalam pembangunan dan pemberdayaan masyarakat yang bertujuan menciptakan kemaslahatan umat, kemandirian dan kepribadian yang bertanggungjawab. Pemerintah Desa Patilereng sangat terbantu dengan adanya Dana Desa dalam pembangunan sarana dan prasarana desa serta berjalannya program pemberdayaan masyakarat.

Peningkatan pembangunan yang islami di Desa Patilereng Kecamatan Bontosikuyu Kabupaten Kepulauan Selayar sudah bisa dikatakan baik karena sudah berdasarkan konsep pembangunan secara islam yaitu: prinsip tauhid, nubuwah (meneladani sifat nabi), kepemilikan, keadilan, keseimbangan, maslaha dan tolongmenolong.

a. Prinsip Tauhid

Tauhid sebagai prinsip pertama dalam ekonomi islam. Prinsip tauhid harus dimiliki oleh manusia karena di dalamnya terdapat aturan serta hukum dalam pembangunan dan perekonomian. Tauhid merupakan panduan bagi setiap ummat muslim dalam melangkah, sehingga aktivitas di dunia tidak hanya berorientasi untuk mencari materi saja, melainkan mencari kebahagian dan kemenangan (Falah) di akhirat.

Berdasarkan teori di atas prinsip tauhid yang ditanamkan kepada masyarakat desa Patilereng yaitu ketika pembangunan sarana tempat beibadah dengan gotong-royong untuk membangun masjid ataupun musalla, masyarakat hadir ikut serta dalam pembangunan dari tahap perencanaan sampai tahap pelaksanaannya.

b. Prinsip Nubuwah

Menurut Adiwarman, prinsip nubuwah mengajarkan kepada ummat islam untuk senantiasa meneladani sifat-sifat yang dimiliki Nabi Muhammad SAW yaitu: siddiq, amanah, tabligh dan fatanah. Berdasarkan teori yang dikemukakan oleh Adiwarman, dalam praktiknya pemerintah Desa Patilereng berupaya mempertanggungjawabkan apa yang menjadi amanah bagi pemerintah desa yaitu mengelola Dana Desa dengan jujur dan amanah dengan merangkul semua lapisan masyarakat yang ada di desa tersebut.

\section{c. Prinsip Kepemilikan}

Prinsip dasar kepemilikan menurut ekonomi islam adalah: a) pemilik bukanlah pengusaha mutlak atas sumber daya alam yang tersedia, tetapi pemilik dituntut untuk memanfaatkan sumber daya alam baik untuk dirinya ataupun orang lain, karena apa yang ada di bumi dan langit adalah mutlak milik Allah SWT; b) batas kepemilikan manusia hanya pada saat manusia itu hidup di dunia; dan c) sumber daya menyangkut kepentingan umum dan menjadi hajat orang banyak tidak boleh dimiliki secara individu.

Berdasarkan prinsip dasar kepemilikan menurut ekonomi Islam, di dalam praktiknya pemerintah desa Patilereng memanfaatkan dan bukan menguasai sepenuhnya dana desa melainkan digunkan untuk meningkatkan pembangunan sarana dan prasarana agar masyarakat dapat menjadi sejahtera dalam perekonomian ataupun secara kualitas hidup.

\section{d. Prinsip Keseimbangan}

Konsep keseimbangan yang tidak hanya mengukur kebaikan dan hasil usaha yang diarahkan untuk dunia dan akhirat saja, tetapi berkaitan juga tentang kepentingan (kebebasan) perorangan dengan kepentingan umum yang harus dipelihara antara keseimbangan antara hak dan kewajiban. 


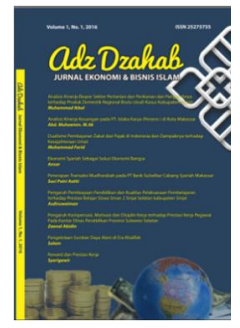

Adz Dzahab

Jurnal Ekonomi dan Bismis Islam

Volume 6, No. 1, 2021

ISSN (print) : 2527-5755

ISSN (online) : :2751-1905

Homepage $\quad: \underline{\text { http://journal.iaimsinjai.ac.id/index.php/adz-dzahab }}$

Dalam wawancara dengan tokoh agama, berpendapat bahwa pemerintah desa Patilereng pada pengelolaan dana desa bersama masyarakat dan lembaga yang ada dan bermusyawarah dalam menentukan arah pembangunan melalui program Dana Desa.

Berdasarkan penjelasan di atas dapat disimpulkan bahwa konsep keseimbangan pada pengelolaan di desa Patilereng telah terealisasi dilihat dari pembangunan dan pemberdayaan yang dilakukan pemerintah desa Patilereng.

e. Prinsip Keadilan

Dari wawancara dengan Bapak khaer selaku masyarakat desa patilereng mengatakan bahwa pemberdayaan yang dilaksanakan pemerintah desa berdasar dari kesepakatan bersama dalam pemenuhan kebutuhan masyarakat, dari usulan-usulan yang diambil dari perwakilan setiap RT atau dusun yang berpartisipasi pada musyawarah desa.

Berdasarkan wawancara di atas dapat disimpulkan bahwa keadilan dalam pengelolaan dana desa dalam pembangunan dan pemberdayaan masyarakat dapat dilihat dari pemenuhan kebutuhan masyarakat sesuai usulan dari perwakilan setiap dusun.

f. Prinsip maslahah

Prinsip maslahah yaitu dengan melakukan aktivitas atau kegiatan untuk hal-hal yang mengacu pada kepentingan bersama. Aktivitas yang dapat dilakukan untuk kemaslahatan Bersama adalah melakukan hal yang bermanfaat serta terhindar dari hal yang membawa kerusakan (mafsadah) bagi manusia.

Dari wawancara oleh Ibu Asmi selaku Kaur perencanaan desa patilereng, dengan adanya pemberdayaan, pegadaan pelatihan dan pembukaan desa wisata (Punagaang dan air terjun) di desa Patilereng diharapkan mempu menjaga serta dapat membuka lapangan kerja bagi masyarakat yang bertujuan untuk mensejahteraan masyarakat desa.

g. Prinsip Persaudaraan (ukhuwah) dan Tolong-menolong (ta'awun)

Prinsip persaudaraan ( $u k h u w a)$ merupakan identitas sebagai sesama muslim adalah saudara. Sedangkan, tolong-menolong ( $t a$ 'awun) merupakan wujud kepedulian terhadap sesama umat muslim dalam meringankan bebannya, sehingga dapat terwujud kegiatan ekonomi yang bermanfaat untuk semua pihak. Adapun contoh persaudaraan dan saling tolong-menolong dalam pemberdayaan di Desa Patilereng yaitu dalam memberikan pelatihan-pelatihan dan pembentukan kelompok tani. Dalam pembentukan kelompok tani ini tidak melihat si miskin ataupun si kaya, semua dilatih dengan kemampuannya masingmasing meskipun pemberdayaan yang dilakukan oleh pemerintah desa masih kurang merata.

Dapat disimpulkan bahwa efektivitas pengelolaan dana desa dalam upaya meningkatkan pembangunan sudah sesuai dengan prinsip islami karena ditinjau dari beberapa aspek antara lain: prinsip tauhid, prinsip nubuwa, prinsip kepemilikan, prinsip keadilan dan tolong menolong.

Hasil penelitian di atas, mengenai pengelolaan dana desa dalam bingkai perspektif islam juga selaras dengan penelitian yang dilakukan oleh Hidayah (2018), menyatakan bahwa pembangunan di desa memberikan dampak yang positif apabila desa tersebut menerapkan prinsip islami, karena memberikan kemaslahatan bagi masyarakat setempat baik dari aspek ekonomi maupun aspek sosial. Sekaligus dapat menjadi program pembangunan desa yang bertujuan untuk mengentaskan kemiskinan desa.

\section{SIMPULAN}

Berdasarkan hasil penelitian dan pembahasan mengenai efektivfitas Pengelolaan Dana Desa dalam meningkatkan pembangunan yang islami di Desa Patilereng Kecamatan Bontosikuyu Kabupaten Kepulauan Selayar, maka dapat ditarik kesimpulan bahwa dalam 


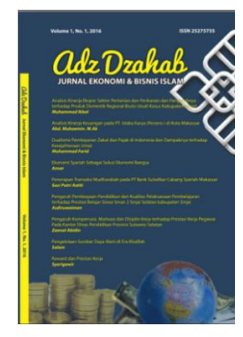

Volume 6, No. 1, 2021

ISSN (print) : 2527-5755

ISSN (online) : 2751-1905

Homepage : $\quad$ http://journal.iaimsinjai.ac.id/index.php/adz-dzahab

proses pengelolaan ada tiga tahap yaitu perencanaan, pelaksanaan dan pertanggungjawaban.

1. Tahap perencanaan dikihat dari kegiatan musyawarah perencanaan pembangunan (musrembang). Di mana dalam kegiatan musrembang ini banyak masyarakat berpartisipasi dalam kegiatan tersebut.

2. Tahapan pelaksanaan berdasarkan hasil penelitian bisa dikatakan sudah efektif karena pemerintah desa patilereng telah melibatkan masyarakat dalam pelaksaan pembangunan dan swasta sebagai pembantu untuk menyediakan bahan material untuk kelancaran pembangunan yang dilakukan oleh desa Patilereng.

3. Tahap pertanggungjawaban dalam proses pengelolaan dana desa dalam meningkatkan pembangunan di desa Patilereng sudah dikatakan efektif karena penyusunan laporan pertanggungjawaban dibuat langsung oleh pemerintah (TPK dan Bendahara Desa) yang diketahui oleh kepala desa Patilereng.

Sementara peningkatan pembangunan yang islami di Desa Patilereng Kecamatan Bontosikuyu Kabupaten Kepulauan Selayar sudah bisa dikatakan baik karena sudah berdasarkan konsep pembangunan secara islam yaitu: prinsip tauhid, nubuwah (meneladani sifat nabi), kepemilikan, keadilan, keseimbangan, maslahah dan tolongmenolong.

\section{Daftar Pustaka}

Endang, Juliana. (2017). Efektivitas Pemanfaatan Dana Desa dalam Menunjang Pembangunan Pedesaan di Kabupaten Asahan. Jurnal Repositori Institusi, Universitas Sumatera Utara.

Hafid, Risma. (2017) Pemanfaatan Dana Desa Dalam Pembangunan Desa Mangilu Kecamatan Bungoro Kabupaten Pangkep Tahun 2016. Jurnal Repositori, Univeristas Hasanuddin.

Hernowo, Basah. (2004). Kajian Pembangunan Ekonomi Desa Untuk Mengatasi Kemiskinan. Artikel Jurnal, Vol. 1, No. 1.

Hidayah, Ummi Nurul. (2018). Analisis Strategi Program Pembangunan Desa Dalam Pengentasan Kemiskinan Perspektif Ekonomi Islam: Studi Kasus Desa Tambakbulusan Kecamatan Karangtengah Demak. Institutional Repository Walisongo.

Lili, Marselina Ara. (2018). Pengelolaan alokasi dana desa dalam upaya meningkatkan pembangunan ekonomi masyarakat di desa magmagan karya kecamatan lumar. Artikel Ilmiah Ekonomi Dan Bisnis Universitas Tanjungpura.

Peraturan Menteri Dalam Negeri No 20 Tahun 2018 Tentang Pengelolaan Keuangan Desa, Physical Review B.

Putriyanti, Aprisiami. (2012). Penerapan Otonomi Desa Dalam Menguatkan Akuntabilitas Pemerintahan Desa Dan Pemberdayaan Masyarakat Di Desa Aglik, Kecamatan

Grabag, Kabupaten Purworejo. In Universitas Negeri Yogyakarta.

Siti, Andi dan Hutami, Sri. (2017). Analisis Pengelolaan Alokasi Dana Desa (ADD) Di Desa Abbatireng Kecamatan Gilireng, Kabupaten Wajo. Jurnal Repositori, Universitas Hasanuddin.

Sofiyanto, M., Mardani, R. M., and Salim, M. G. (2017). Pengelolaan Dana Desa Dalam Upaya Meningkatkan Pembangunan Di Desa Banyuates Kecamatan Banyuates Kabupaten Sampang. Jurnal Riset Manajemen.

Sumianto, La. (2018). Efektifitas Pengelolaan Alokasi Dana Desa Dalam Meningkatkan Pembangunan Fisik Di Desa Kampo-Kampo Kecamatan Binongko Kabupaten 


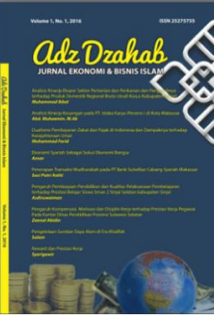

Adz Dzahab

Jurnal Ekonomi dan Bisnis Islam

Volume 6, No. 1, 2021

ISSN (print) : 2527-5755

ISSN (online) : :2751-1905

Homepage $\quad:$ http://journal.iaimsinjai.ac.id/index.php/adz-dzahab

Wakatobi.

Kybernan:

Jurnal

Studi

Kepemerintahan.

https://doi.org/10.35326/kybernan.v3i1.338

Thomas. (2013). Pengelolaan Alokasi Dana Desa Dalam Upaya Meningkatkan Pembangunan Di Desa Sebawang Kecamatan Sesayap Kabupaten Tana Tidung.ejorunal Pemerintahan intergratif. Ejurnal.

Undang-Undang No 32 Tahun 2004, T. P. D. (2004). Undang-Undang No 32 Tahun 2004 Tentang Pemerintah Daerah. Dpr.

Undang - Undang no 6 Tahun 2014. (2014). Undang-Undang Nomor 6 Tahun 2014

Tentang Desa. Undang - Undang No 6 Tahun 2014. https://doi.org/10.1017/CBO9781107415324.004. 